\title{
Abszolút hozamú befektetési alapok teljesítményének értékelése - a teljesítménymanipulálás kimutatása
}

\begin{abstract}
Számos mutatószámmal és megközelítéssel lehet értékelni az aktívan menedzselt befektetési alapokat. A teljesítményértékelésben fontos probléma a manipulálhatóság, amely nemcsak az abszolút hozamú, hanem minden befektetési és fedezeti alapot érintő jelenség. Ebben a cikkben elsőként prezentáljuk a manipulációbiztos mutatószámok alkalmazását magyar befektetési alapok teljesítményértékelésére, valamint a hozammanipuláció nyomainak kimutatására. Megmutatjuk továbbá, hogy az elemzett magyar adatokon nem egyértelmú a kételkedési hányadosnak a szakirodalomban megfigyelt, az alternatív hozammanipulációt kimutató módszerekkel való szoros átfedése (Brown és szerzőtársai [2010] alapján 80 százalékos egyezés). Eredményeink alapján a torzítási ráta a potenciális hozammanipuláció kimutatására jobb előszürő eszköznek bizonyult, mint a kételkedési hányados.* Journal of Economic Literature (JEL) kód: C10, G11, G24C10, G11, G24.
\end{abstract}

Ebben a cikkben először azt a kérdést járjuk körül, hogy miként értékeljük az abszolút hozamú befektetési alapok teljesítményét. Az abszolút hozamú befektetési alapok aktívan menedzseltek, és - eltéröen a többi befektetési alaptól - nem követnek referenciaértékeket (benchmarkokat) vagy -indexeket, hanem céljuk az, hogy minden piaci körülmény között pozitív hozamot érjenek el alacsony volatilitás mellett. Ez egyrészt azáltal lehetséges, hogy szofisztikáltabb pénzügyi termékeket - például származtatott termékeket - is beépítenek a portfóliójukba, és így védekeznek a veszteségek kockázatával szemben. Másrészt az alapkezelő nemcsak abban kap szabad kezet, hogy nem egy elöre megadott indexet kell követnie minden piaci körülmény között, hanem szabadabban dönthet az egyes eszközosztályok és befektetések portfólión belüli arányáról, szemben a hagyományos befektetési alapokkal, ahol a minimum- és maximumarányok is elő vannak írva,

* Köszönöm Csóka Péternek és Pintér Miklósnak, hogy értékes észrevételeikkel és javaslataikkal segítették a munkámat.

Rácz Dávid Andor a Budapesti Corvinus Egyetem Gazdálkodástani Doktori Iskolájának doktorjelöltje

(e-mail: raczdavidandor@gmail.com).

A kézirat első változata 2019. február 13-án érkezett szerkesztőségünkbe.

DOI: http://dx.doi.org/10.18414/KSZ.2019.7-8.824 
így még akkor sem csökkenthetik le egy adott eszközosztály arányát egy szintnél alacsonyabbra, ha megítélésük szerint a piaci viszonyok ezt tennék szükségessé. Így akkor sem kerülhetnek el bizonyos veszteségeket, ha egyébként erre szakmai helyzetértékelésük alapján képesek lennének.

A szakirodalomból világos, hogy a klasszikus teljesítményértékelő mutatószámok alkalmazása több esetben problémákat vet fel (Pojarliev-Levich [2013], Ingersoll és szerzötársai [2007]). Az abszolút hozamú befektetési és fedezeti alapok esetében ezért új teljesítményértékelő mutatószámokat kell építeni, amelyek függetlenek a referenciaértékektől, és akkor is képesek a kockázat-hozam kombinációk helyes értékelésére, ha a befektetési alap hozameloszlása abnormális. E probléma egyik lehetséges megoldása a manipulációbiztos teljesítménymutatók (Manipulation Proof Performance Measure, MPPM) alkalmazása, amelyek a mikroökonómiából jól ismert hasznosságelméleten alapulnak. Ezek konstrukciójuknak köszönhetően kifejezetten alkalmasak aktívan menedzselt alapok értékelésére, mert értéküket csak tényleges információ/képesség birtokában, a befektető hasznosságát ténylegesen növelö, valódi hozzáadott értéket teremtő befektetési döntésekkel lehet növelni. Míg pusztán annak ismeretében, hogy milyen mutatóval mérik a teljesítményt, ez nem lehetséges, szemben a klasszikus mérőszámokkal, amelyeket csupán a méröszám ismeretével, többlettudás és többletinformáció nélkül is lehet manipulálni (Ingersoll és szerzőtársai [2007]).

$\mathrm{Az}$ általunk vizsgált második kérdéskör: van-e nyoma hozammanipulációnak vagy hozamsimításnak a magyar abszolút hozamú befektetési alapok esetében? Annak kimutatása a manipulációbiztos teljesítménymutatóra épülő kételkedési hányadossal vagy más alternatív módszerekkel hatékonyabb-e? Az eredményeink a szakirodalomban látottakkal szemben azt mutatják, hogy a torzitási ráta a potenciális hozammanipuláció kimutatásának jobb előszűrő eszköze, mint a kételkedési hányados. Így elsősorban a torzitási ráta eredményei alapján ajánlott további, részletesebb elemzéseket végezni, például diszkontinuitáselemzéssel.

A cikk felépítése a következő: először a szakirodalomban elterjedt teljesítménymutatókat ismertetjük, majd bemutatjuk a saját eredményeink számításához felhasznált módszertant, valamint a hazai abszolút hozamú befektetési alapok elemzését a manipulációbiztos teljesítménymutatókkal, illetve a hozammanipuláció nyomainak kimutatását különböző módszerekkel. Végül egy rövid összefoglalással zárjuk a dolgozatot.

\section{Teljesítményértékelő mutatószámok}

A következőkben áttekintjük az irodalomban és az alkalmazásokban előforduló teljesítményértékelő mutatószámokat, bemutatva felépítésüket, a felépítésükhöz használt gondolatmenetet, illetve azt, hogy az egyes változatok a korábbiaknak milyen hibáit igyekeztek kezelni, és hogy az aktívan menedzselt alapok - különösen az abszolút hozamú alapok - esetében milyen hiányosságok lépnek fel, ami miatt alternatív mutatószámok keresése felé kell fordulnunk. 
A szakirodalomban számos szempontja van az aktívan menedzselt portfóliók értékelésének (Pojarliev-Levich [2013], Ingersoll és szerzőtársai [2007], Zawadowski [2017], Erdős és szerzőtársai [2011], Walter [2002]). Jellemzően a következő mutatószámokkal találkozhatunk az irodalomban: Jensen-alfa (Jensen [1969]), Sharpe-ráta (Sharpe [1966]), Sortino-ráta (Sortino-Van der Meer [1991], Sortino [2001]), Treynor-ráta (Treynor [1965]), információs ráta (Treynor-Black [1973]), M2 (Modigliani-Modigliani [1997], a kockáztatott érték (Value-at-Risk, VaR) (Jorion [1996]), Expected Shortfall (ES) (Rockafellar-Uryasev [2001], Acerbi-Tasche [2002]) stb. Bár ezek a klasszikus teljesítményértékelö mutatószámok széles körben alkalmazottak az aktívan menedzselt befektetési alapok teljesítményének mérésére, könnyen belátható, hogy alkalmazásuk számos esetben nem egyértelmü és nem problémamentes (Ingersoll és szerzötársai [2007]). Ezekből hármat mutatunk be részletesebben, rámutatva a mutatószámok elméleti és gyakorlati problémáira, valamint az ezen problémák kiküszöbölését célzó, a mutatószámok között megfigyelhető fejlődésre.

A Sharpe-rátát (Sharpe [1966]) teljesítményértékelésre használva „csak” arra kapunk választ, hogy a befektetési alap megfelelö többlethozamot biztosít-e egységnyi vállalt többletkockázatért, azonban a mutató arról nem ad információt, hogy milyen a kapcsolat a referenciaindex és a befektetési alap teljesítménye között, azaz nem bontja meg a befektetési alap teljesítményét a piaci, illetve a referenciaindex változásából fakadó teljesítményre, valamint a befektetésialap-kezelő egyedi döntéseiből fakadó teljesítményre. Így a használatával nem kapunk információt arról, hogy az alapkezelő pontosan milyen módon teljesített felül vagy alul a referenciaindexhez képest.

Erre a kérdésre próbál válaszolni a Jensen-alfa (Jensen [1969]), amely a szakirodalomban az egyik legelterjedtebben használt mutató, mivel közérthetően mutatja az alul- vagy felülteljesítést a referenciaindexhez viszonyítva, és a kiszámítása is viszonylag egyszerü. Ugyanakkor csak azt mutatja meg, hogy milyen hozamot ért el az alapkezelö a referenciaértékhez viszonyítva, de hogy ehhez milyen többletkockázatot vállalt, azt nem. Így általa nem tudjuk meg, hogy mennyivel kockázatosabb az alapkezelő felülsúlyozásaival kialakított portfólió a referenciaértékekhez viszonyítva.

Az információs ráta (Treynor-Black [1973]) ezt a problémát kezelve azt mutatja meg, hogy az alapkezelő az aktívan vállalt kockázati egységre vetítve milyen többlethozamot ért el (Jensen-alfa a Jensen-alfa szórására vetítve). Az információs ráta lényegében a Sharpe-ráta módosítása, ahol a többlethozamot a kockázatmentes hozam helyett a referenciaértékhez viszonyítjuk, és a referenciaindexhez képest vállalt többletkockázathoz arányosítjuk. Az abszolút hozamú alapok esetében azonban nem magától értetődő, hogy mi az a referenciaindex, amelyhez viszonyítva helyes teljesítményértékelésre juthatunk, mivel ezen befektetési alapok nem követnek egyértelmüen és jól meghatározott indexet vagy indexeket. Ehelyett minden piaci körülmény között pozitív hozam elérése a kitüzött céljuk, alacsony volatilitás mellett.

A piaci gyakorlat szerint az abszolút hozamú alapok esetében a referenciaindex a kockázatmentes hozam vagy állampapíroknak egy meghatározott indexe. Ez a megközelítés ugyanakkor összekeveri a referenciaindexre (-indexekre) való 
kitettségből vagy érzékenységből származó hozamot, valamint a referenciaértékekhez viszonyított többlethozamot, a Jensen-alfát. Mivel a befektetési alap kockázatos eszközökbe is fektet, a hozamának egy része értelemszerüen a referenciaindexekre való érzékenységből fakad. Így helytelen a Jensen-alfákat a kockázatmentes hozamból mint referenciaindexből levezetni, mert a kimutatott Jensen-alfák nagyságának jelentős hányadát valójában nem az alapkezelő hozzáértése magyarázza, hanem az, hogy az általa választott összetételü portfólió kockázatos index(ek)et követ.

\section{Alfa-ráta}

Az előbbiekben tárgyalt probléma miatt nem magától értetődő feladat az abszolút hozamú befektetési alapok esetében, hogy miként azonosítsuk a befektetési alap hozamának a megfelelő referenciához (benchmarkhoz) társítható részét, és így az információs ráta számítását is módosítani kell. Az egyik lehetséges megoldás a kockázati tényezőkre épülő keret használata. Ezek a tényezők különféle befektetési stílusokat vagy különböző kockázati tényezőket jeleníthetnek meg. Segítségükkel az abszolút hozamú befektetési alapok esetében is viszonylag pontosan szétválasztható a különféle kockázati tényezők követéséből fakadó piaci hozam és referenciahozam, valamint az alapkezelö egyedi tudásából, saját befektetési döntéseiből fakadó hozam. PojarlievLevich [2013] a módosított információs rátát alfa-rátának nevezi $\left(I R^{*}\right)$ :

Alfa-ráta $=I R^{*}=\frac{\hat{\alpha}}{\sigma_{\hat{\alpha}}}$,

ahol

$\hat{\alpha}=R_{p}-\sum_{i} \hat{\beta}_{i t} F_{i t}+e_{t}$,

továbbá $R_{p}$ a befektetési alap hozama, $F_{i t}$ a különféle kockázati tényezők és befektetési stílusok, $\hat{\beta}_{i t}$ a befektetési alap hozamának a különböző kockázati tényezőkre való érzékenysége, $e_{t}$ pedig a becslési hiba.

\section{Az alkalmazott módszertan}

A manipulációbiztos teljesítménymutatók jelentik a másik megoldást az abszolút hozamú befektetési alapok teljesítményének a helyes értékelésére, emellett felhasználhatók bármilyen befektetési és fedezeti alap értékelésére is. Sajátos konstrukciójuknak köszönhetöen a helyes teljesítményértékelés mellett még azzal a tulajdonsággal is rendelkeznek, hogy ellenállnak a különféle manipulációs kísérleteknek. Mielőtt rátérünk a saját számításainkra, át kell tekintenünk röviden a manipulációbiztos teljesítménymutatók hátterét, illetve a számításainkhoz felhasznált módszertant. 


\section{Manipulációbiztos teljesítménymutatók}

Manipulációbiztosságon nem a mikroökonómiában közismert GibbardSatterthwaite-tétel (lásd például Mas-Colell és szerzötársai [1995] 23. fejezet) szerinti manipulációmentességet értjük. Itt ugyanis nem egy társadalmi választási függvény manipulációval való sebezhetőséget vizsgáljuk. Ehelyett itt azt szeretnénk biztosítani, hogy az alapkezelö menedzser ne tudja pusztán azáltal növelni a saját teljesítményalapú javadalmazását, valamint bónuszait, hogy ismeri az értékelésére használt teljesítménymutatót. Ne létezzenek olyan befektetési döntések, amelyek bár nem növelik ténylegesen a befektetési alapot birtokló befektetők hasznosságát, mégis növelik az értékelésre használt mutatószám értékét (például jelentésbeli simításokkal átlagolt hozameredményekkel csökkentve a szórást). Olyan értékelési rendszer alkalmazása a célunk tehát, amely csak azokat a befektetési döntéseket jutalmazza, amelyek ténylegesen növelik a befektetők hasznosságát, amelyeket tehát csak olyan alapkezelő menedzserek képesek végrehajtani, akiknek vagy többletinformációik, vagy jobb képességeik vannak a piacnál, és ezekre építve valóban képesek kockázattal korrigált többlethozamot generálva eltérni a piaci indexet leképező portfólió-összetételtől.

A klasszikus teljesítménymutatók esetében Ingersoll és szerzötársai [2007] megmutatta, hogy azok manipulálhatók, sőt azt is, hogy hogyan. Léteznek olyan kereskedési és jelentési eljárások, amelyek növelik ugyan a mutatók értékeit, de nem növelik a befektetők hozam-kockázat térben értelmezett hasznosságát. Ugyanakkor létezhet olyan jól megkonstruált teljesítménymutató, amely hasznossági alapú megközelítéssel kiküszöböli a fenti problémákat (Ingersoll és szerzőtársai [2007]). További elönye a manipulációbiztos teljesitménymutatóknak, hogy előfeltevéseikhez nem tartozik a hozamok normális eloszlásának feltevése, így eredményeik kevésbé torzulnak a valós életben tapasztalt ferde és vastag szélü hozameloszlások esetében, szemben a klasszikus teljesítménymutatókkal.

Ingersoll és szerzőtársai [2007] a manipulációbiztos teljesitménymutatókat (MBTM) a következö feltételekkel jellemezték:

1. egy egyedi értékszámot kell adnia a rangsoroláshoz;

2. az elért értékszámnak nem szabad függenie a portfólió pénzben kifejezett értékétől, csak a százalékban mért hozamtól;

3. informálatlan befektetők nem érhetnek el magasabb becsült értékszámot, ha eltérnek a referenciaindextől, az informált befektetők azonban arbitrázslehetőségek használata által igen;

4. a mutatószámnak konzisztensnek kell lennie az általános pénzpiaci egyensúlyi feltételekkel.

Ha e feltevések közül bármelyik nem teljesül, akkor létezik legalább egy olyan módszer, amellyel aktív portfóliókezelők képesek az értékszámuk javítására, manipulálására olyan stratégiák alkalmazásával, amelyek látszólag jobb kockázat-hozam elosztásokhoz vezetnek, de a valóságban úgy érnek el magasabb értékszámot, hogy mögöttük nincs valós teljesítmény, nem növelik a befektetö hasznosságát. 
Az 1. feltétel kizárja azokat a mutatószámokat, amelyek csak részben állítanak fel sorrendet, továbbá az olyan használhatatlan mutatószámokat, amelyek egyszerüen csak az elérhető hozamokat állítják egy listába.

A 2. feltétel egyszerüen azt mondja ki, hogy a hozamok önmagukban elégséges statisztikák, míg a pénzben mért nyereségek és veszteségek nem. Így például az alap nettó eszközértékének abszolút nagysága nem lehet mérvadó a rangsorolásban, mivel pusztán azért, mert egyik alap nagyobb vagyontömeggel rendelkezik, mint a másik, az még nem jelenti azt, hogy az egyik alap jobban is teljesít, mint a másik.

A 3. és 4. feltétel azt foglalja össze, hogy az informálatlan befektetők nem profitálhatnak a referenciaindextől való eltérésből, például azzal, hogy megpróbálják megváltoztatni a befektetési alap értékszámát a megfigyelhető adatokon, míg az arbitrázslehetőségek kihasználásából eredő többletteljesítménynek valóban tükröződnie kell az értékszámban. Tehát például egyszerű hozamsimítással, akár kiátlagolt hozamok manipulált lejelentésével, akár egy szerencsés időszak utáni kockázatmentes befektetésre való teljes áttéréssel lecsökkentett volatilitással, ne lehessen hozzáadott érték vagy információ nélkül javítani a mutatószám értékét.

Ugyanakkor a tényleges hasznosságot növelő befektetési döntéseket a mutatónak ki kell mutatnia, és ezzel összhangban egyre magasabb értékeket kell társítania az ilyen eredményekhez. Ingersoll és szerzötársai [2007] megmutatja, hogy ezek a feltételek akkor teljesülnek, ha a mutatószám:

1. növekedö a hozamokra (monoton),

2. konkáv,

3. időben szeparábilis,

4. hatványfüggvény formájú.

Az 1. feltétel azt biztosítja, hogy a mutatószám elismeri az arbitrázslehetőségeket. A 2. feltétel azt akadályozza meg, hogy pusztán a tőkeáttétel növelése vagy a beárazatlan kockázat hozzáadása által magasabb értékszámot lehessen elérni. Másképpen megfogalmazva, nemcsak az elért hozam nagysága, hanem a vállalt kockázat is számít. A 3. feltétel a dinamikus, azaz időbeli manipulációt akadályozza meg. A 4. feltétel biztosítja a konzisztenciát a pénzpiaci egyensúlyelmélettel, és azért kell különböző időpontokból venni a különböző hozamokat, hogy helyettesítsék a különböző kimenetekből származó hozamokat.

A $\hat{\Theta}$ - az Ingersoll és szerzőtársai [2007] által javasolt mutató - teljesíti a fenti feltételeket:

$$
\hat{\Theta}=\frac{1}{(1-\rho) \Delta t} \ln \left[\frac{1}{T} \sum_{t=1}^{T}\left(\frac{1+r_{t}}{1+r_{f t}}\right)^{1-\rho}\right],
$$

ahol az $r_{t}$ az alap hozama, $r_{f t}$ a kockázatmentes hozam. A $\rho$ a relatív kockázatelutasítási együttható, amelynek az értéke a szakirodalomban megtalálható empirikus adatok alapján általában a 0,2 és 10 közötti tartományban mozog. 
Arrow [1971] alapján az értéke 1 körüli, valamint Szpiro-Outreville [1988] eredményei szerint 1 és 5 közé esik, a hányados átlaga pedig 2,89. Layard és szerzőtársai [2008] szintén 1 körüli értékeket tapasztalt. Friend-Blume [1975] és Kydland-Prescott [1982] szerint 2 körüli, míg Ingersoll és szerzötársai [2007] alapján pedig 2 és 4 közötti tartományban mozog. Gandelman-Hernandez-Murillo [2015] szerint országonként eltérő értéket mutat, 1 körüli jellemző értékkel, és az átlagtól jelentősen eltérő országok értékei is beleférnek a 0-3 tartományba.

A $\hat{\Theta}$ a befektetési alap kockázattal korrigált többlethozamára ad becslést. Egy adott $\hat{\Theta}$-ra a portfóliónak az értékszáma megegyezik egy kockázatmentes eszköznek a folytonos hozamszámítással számított és évesített hozamával, ami a $\hat{\Theta}$ értékével haladja meg a kockázatmentes hozamot.

Mind Ingersoll és szerzőtársai [2007], mind Brown és szerzőtársai [2010] 2 és 4 közötti relatív kockázatelutasítási együtthatókkal számolt. Ingersoll és szerzőtársai [2007] azzal indokolta ezt az alkalmazott tartományt, hogy bár elvileg lehetséges lenne ennél szélesebb intervallummal is számolni az empirikus adatok szerint, de a 2 és 4 közötti relatív kockázatelutasítási együttható olyan portfólióknak felel meg, amelyeknek a tőkeáttétele 1,75 és 0,75 közötti. Ez a tartomány pedig felöleli a legtöbb rangsorolni kívánt alapot. Brown és szerzőtársai [2010] az Ingersoll és szerzőtársai [2007] eredményeivel való összevethetőség miatt döntött a 2 és 4 közötti kockázatelutasítási együtthatók használata mellett. Az összevethetőség miatt mi is 2 és 4 közötti kockázatelutasítási együtthatókkal fogunk számolni a későbbiekben.

A manipulált teljesitmény feltárása a manipulációbiztos teljesítménymutató segítségével

Brown és szerzőtársai [2010] egy alternatív formában az Ingersoll és szerzőtársai [2007]-féle manipulációbiztos teljesítménymutató (MBTM) lineáris közelítését írta fel:

$\hat{\Theta}(\rho)=\frac{1}{\Delta t}\left\{\bar{x}+\frac{1-\rho}{2}\left(s_{x}^{*}\right)^{2}\right\}$,

ahol $\bar{x}$ a többlethozam átlaga, $\left(s_{x}^{*}\right)^{2}=s_{x}^{2}(T-1) / T$ a többlethozam mintából számított varianciája, $\rho$ a relatív kockázatelutasítási együttható, $\Delta t$ pedig az egységnyi időintervallumot jelenti, amelyre a hozamokat számítottuk.

Ez az egyszerüsítés lehetővé tette az úgynevezett kételkedési hányados (Doubt Ratio, $D R$ ) felírását, amely különböző kockázatelutasítási együtthatókkal számolt indexértékekből következtet az implikált kockázatelutasítás alakulására. Amennyiben extrém változásokat mutat ki az implikált kockázatelutasításban, akkor nagy valószínüséggel manipuláció áll a háttérben. Ezt az összefüggést sikerült az empirikus adataikon is kimutatni alternatív statisztikai módszerek alkalmazásával, amelyek más megközelítéssel mutattak ki jelentésbeli, illetve hozammanipulációt. A szerzők mindezekből arra következtettek, hogy a kételkedési hányados segítségével is megbízhatóan azonosíthatók a hozammanipulációk. 
A kételkedési hányados $(D R)$ képlete:

$D R=\frac{\hat{\Theta}(2)}{\hat{\Theta}(2)-\hat{\Theta}(3)}+2 \approx \frac{2 \bar{x}}{\left(s_{x}^{*}\right)^{2}}+1$.

Brown és szerzőtársai [2010] szerint a lejelentett hozamok kisimítása lehet a legáltalánosabb mód az alapok teljesítményének manipulálására, mivel csökkenteni képes a hozamok volatilitását, miközben az átlaghozamot változatlanul hagyja. Javíthatja a Sharpe-ráta értékét, de az MBTM értékét nem, mivel az a többlethozam átlagának és varianciájának különbségére épül. A vizsgált adataikon a szerzőknek sikerült bizonyítaniuk, hogy az MBTM ellenáll a hozammanipulációnak: az alternatív statisztikai módszerek szerint is manipuláltnak mért fedezeti alapok esetében az MBTM és a klasszikus mutatószámok közötti rangkorreláció értéke alacsonyabb, mint a klasszikus mutatószámok közötti, mivel a klasszikus mutatószámok hasonlóan torzulnak a manipulációk hatására. Ezzel szemben a kontrollmintaként a Hasanhodzic-Lo [2007] lineárisfaktor-modelljével a fedezeti alapokra számított torzításmentes replikált hozamok esetében a várakozásoknak megfelelően a rangkorreláció a különböző kockázatelutasítási együtthatókkal számolt MBTM-ek és a klasszikus teljesítménymérö mutatószámok között ugyanolyan, mint a klasszikus mutatószámok között, mivel - azok konstrukciójának megfelelően - definíció szerint nincs manipuláció a hozamokban.

\section{Magyarországi abszolút hozamú befektetési alapok elemzése}

Saját számításokat végeztünk a Magyarországon forgalmazott, forintban denominált abszolút hozamú alapok esetében. A vizsgálat arra tért ki, hogy van-e lényeges eltérés a klasszikus mutatószámok (Sharpe-ráta) és az MBTM között, illetve figyelembe véve a kételkedési hányadost, a torzitási rátát és a diszkontinuitáselemzést is, találunk-e olyan alapokat, ahol kirívóan magas a manipuláció vagy egyéb anomália esélye.

Harminckét olyan befektetési alapot választottunk ki az elemzésünk számára (1. táblázat), amelyek az abszolút hozamú befektetési alapok kategóriájába tartoznak, forintban vannak denominálva, folyamatos kereskedési múltjuk legalább hétéves, és a hozamadataik elérhetők a Bamosz (Befektetési Alapkezelők és Vagyonkezelők Magyarországi Szövetsége) honlapján (http://www.bamosz.hu).

Az elemzési periódusnak a 2010. április 28. és 2017. április 27. közötti időszakot választottuk, amely 56832 napi hozamot ölelt fel. Kockázatmentes hozamnak az ÁKK 12 havi referenciahozamát használtuk, mivel ez a rövid lejáratú állampapírhozam nemcsak kockázatmentesnek tekinthetö, de jól tükrözi az elemzett időszakban a kockázatmentes hozam lényeges változásait is. Az MBTM Brown és szerzötársai [2010]-féle számításához a 12 havi referenciahozam havi változásait vettük figyelembe, míg a Sharpe-rátához a teljes időszakra számított átlaghozamot használtuk, amire évesített 3,62 százalék adódott.

A Sharpe-rátákat különféle kockázatelutasítási hányadosok mellett hasonlítottuk az alkalmazott $M B T M$-hez. A rangkorrelációk viszonylag magas értéket vettek fel 
1. táblázat

A kiválasztott abszolút hozamú alapok

\begin{tabular}{|c|c|c|}
\hline Sorszám & Alap neve & Alap ISIN kódja \\
\hline 1. & Aberdeen Diversified Growth Alapok Alapja B & HU0000704549 \\
\hline 2. & Aberdeen Diversified Growth Alapok Alapja I & HU0000704556 \\
\hline 3. & Aegon Alfa & HU0000703970 \\
\hline 4. & Aegon MoneyMaxx A & HU0000703145 \\
\hline 5. & Aegon ÓzonMaxx & HU0000705157 \\
\hline 6. & Aegon Smart Money & HU0000708169 \\
\hline 7. & Budapest Kontroll Alap A & HU0000702741 \\
\hline 8. & Citadella Származtatott & HU0000707948 \\
\hline 9. & Concorde Columbus & HU0000705702 \\
\hline 10. & Concorde PB2 & HU0000704705 \\
\hline 11. & Concorde Rubicon & HU0000707252 \\
\hline 12. & Concorde VM & HU0000703749 \\
\hline 13. & Erste DPM Alternatív & HU0000705314 \\
\hline 14. & Erste Multistrategy Abszolút Hozamú Alapok Alapja & HU0000705322 \\
\hline 15. & Generali IPO & HU0000706791 \\
\hline 16. & Generali Spirit & HU0000706833 \\
\hline 17. & Generali Titanium Abszolút Alapok Alapja & HU0000706817 \\
\hline 18. & OTP Abszolút Hozam A & HU0000704457 \\
\hline 19. & OTP EMDA & HU0000706361 \\
\hline 20. & OTP G10 Euró A & HU0000706221 \\
\hline 21. & OTP Supra & HU0000706379 \\
\hline 22. & OTP Új Európa Alap A & HU0000705827 \\
\hline 23. & Platina Alfa & HU0000704648 \\
\hline 24. & Platina Béta & HU0000704655 \\
\hline 25. & Platina Delta A & HU0000704671 \\
\hline 26. & Platina Gamma & HU0000704663 \\
\hline 27. & Platina Pí A & HU0000704689 \\
\hline 28. & Raiffeisen Hozam Prémium Alap A & HU0000703699 \\
\hline 29. & Raiffeisen Index Prémium & HU0000703707 \\
\hline 30. & Raiffeisen Private Pannonia Alapok Alapja A & HU0000705231 \\
\hline 31. & Sovereign PB Származtatott & HU0000707732 \\
\hline 32. & Takarék Invest Abszolút Hozamú Alap & HU0000707997 \\
\hline
\end{tabular}

a 0,87-0,9 sávban (2. táblázat), ami ugyan magasabb a nemzetközi példákban látott 0,7 körüli értékeknél, de még mindig jelez annyi eltérést a klasszikus mutatószámokhoz viszonyítva, amelyet okozhat valamilyen szintủ hozammanipuláció vagy hozamsimítás. 
2. táblázat

Rangkorrelációk a Sharpe-ráta és az MBTM között különböző kockázatelutasítási együtthatókra

\begin{tabular}{lc}
\hline & Sharpe-ráta \\
\hline $\operatorname{MBTM}(2)$ & 0,9051 \\
$\operatorname{MBTM}(3)$ & 0,8981 \\
$\operatorname{MBTM}(4)$ & 0,8724 \\
\hline
\end{tabular}

A rangkorreláció értékei arra utalnak, hogy van néhány alap, amelyek esetében komoly eltérés mutatkozik a Sharpe-ráta szerinti rangsorolás és az $M B T M$ szerinti rangsorolás szerint, különösen az MBTM(4) kockázatelutasítás mellett (1. ábra).

- Az OTP G10 Euró 16. a Sharpe-ráta alapján, de csak 32. az MBTM(4) által rangsorolva,

- A Platina Delta 17. a Sharpe-ráta szerint, de csak a 30. az MBTM(4) alapú rangsorban,

- A Raiffeisen Index Prémium 28. a Sharpe-alapú rangsorban, ám 20. az MBTM(4) szerint,

- A Raiffeisen Hozam Prémium 25. a Sharpe-ráta alapján rangsorolva, viszont 18. az $M B T M(4)$ szerinti rangsorolásban.

Az MBTM szerinti rangsorolás stabilnak mondható, mivel a különböző kockázatelutasítási együtthatókra közel azonos eredményeket ad. A rangkorreláció az MBTM különböző kockázatelutasítási együtthatóval számolt verziói között nagyon magas értékeket mutat a 0,97-0,99 tartományban. Ahogy a 3. táblázatban látható, a Sharpe-ráta és az $M B T M$-alapú rangsorolás nagyobb eltérést mutat az $M B T M(3)$ alapján legrosszabbnak értékelt alapok esetén, mint az MBTM(3) szerint legjobbnak értékelt alapok esetében. Ennek leginkább az OTP G10 Euró alap az okozója, mert ahogy már említettük, a Sharpe-ráta szerint 16. a sorban, míg az $\operatorname{MBTM(3)~alapján~csak~a~} 32$.

A Citadella, Platina Pí, Platina Alfa sorban a 2., a 3. és a 4. az MBTM szerint, és a 4., az 5. és a 3. a Sharpe-ráta alapján. Ugyanakkor érdekes látni, hogy ezek a befektetési alapok benne vannak a vizsgált alapok közötti legmagasabb öt (top 5) kételkedési hányadossal rendelkezők csoportjában. Bár a vizsgált alapok esetében a legmagasabb kételkedési hányadosok az 50-80 közötti sávban helyezkednek el, ami egyáltalán nem számít kiugró értéknek a szakirodalom alapján. A Concorde Rubicon 1. helyen rangsorolt a 3-as kockázatelutasítási együtthatóval számított MBTM szerint, és 11. a Sharpe-ráta rangsorában, míg az OTP Supra 5. az MBTM rangsorában, és 8. a Sharpe-ráta alapján. Brown és szerzőtársai [2010] szerint az MBTM a többlethozam átlagának és varianciájának a különbsége, és így kevésbé bünteti a szórást, mint a Sharpe-ráta. A Concorde Rubicon és az OTP Supra is a legjobb ötbe tartozik az $M B T M$ rangsorában, pedig az egyik legmagasabb szórással rendelkeznek a vizsgált mintában (21. és 29. legkevésbé biztonságosak a 32 befektetési alapból). 
3. táblázat

Az MBTM alapján legjobbnak és legrosszabbnak rangsorolt alapok tulajdonságai

\begin{tabular}{lccccc}
\hline Mutató & \multicolumn{5}{c}{ Legjobb öt alap MBTM(3) alapján } \\
\cline { 2 - 6 } & $\begin{array}{c}\text { Concorde } \\
\text { Rubicon }\end{array}$ & Citadella & $\begin{array}{c}\text { Platina } \\
\text { Pí }\end{array}$ & $\begin{array}{c}\text { Platina } \\
\text { Alfa }\end{array}$ & $\begin{array}{c}\text { OTP } \\
\text { Supra }\end{array}$ \\
\hline Átlagos hozam & 10,84 & 4,00 & 9,40 & 9,21 & 13,36 \\
Az átlagos hozam szerinti rangsor & 3. & 4. & 5. & 6. & 2. \\
A hozam szórása & 7,39 & 4,47 & 4,67 & 4,19 & 15,19 \\
A hozam szórása szerinti rangsor & 24. & 12. & 14. & 10. & 29. \\
Sharpe-ráta & 0,98 & 1,34 & 1,24 & 1,33 & 0,64 \\
Sharpe-ráta szerinti rangsor & 6. & 1. & 3. & 2. & 8. \\
MBTM(2) & 0,0651 & 0,0579 & 0,0556 & 0,0543 & 0,0615 \\
MBTM(3) & 0,0624 & 0,0569 & 0,0545 & 0,0535 & 0,0488 \\
MBTM(4) & 0,0597 & 0,0559 & 0,0534 & 0,0526 & 0,0361 \\
Kételkedési hányados & 25,88 & 59,98 & 53,02 & 64,07 & 6,84 \\
Kételkedési hányados szerinti & 22. & 29. & 28. & 31. & 19. \\
rangsor & & & & & 2. \\
MBTM(2) rangsor & 1. & 3. & 4. & 5. & 2. \\
MBTM(3) rangsor & 1. & 2. & 3. & 4. & 5. \\
MBTM(4) rangsor & 1. & 2. & 3. & 4. & 7. \\
\hline
\end{tabular}

Legrosszabb öt alap MBTM(3) alapján

OTP G10 Sovereign Generali Erste Generali

Euró $\quad \mathrm{PB} \quad$ Spirit Multistrategy Titanium

\begin{tabular}{lccccc}
\hline Átlagos hozam & 7,03 & $-1,17$ & 0,45 & 0,79 & 1,33 \\
Az átlagos hozam szerinti rangsor & 9. & 32. & 31. & 30. & 29. \\
A hozam szórása & 22,07 & 5,76 & 6,95 & 5,60 & 6,96 \\
A hozam szórása szerinti rangsor & 32. & 17 & 21 & 16 & 22 \\
Sharpe-ráta & 0,15 & $-0,83$ & $-0,46$ & $-0,51$ & $-0,33$ \\
Sharpe-ráta szerinti rangsor & 16. & 32 & 30 & 31 & 27 \\
MBTM(2) & $-0,0375$ & $-0,0523$ & $-0,0378$ & $-0,0319$ & $-0,0291$ \\
MBTM(3) & $-0,0617$ & $-0,0542$ & $-0,0403$ & $-0,0335$ & $-0,0316$ \\
MBTM(4) & $-0,0859$ & $-0,0561$ & $-0,0427$ & $-0,0351$ & $-0,0341$ \\
Kételkedési hányados & 0,45 & $-25,40$ & $-13,48$ & $-18,25$ & $-9,84$ \\
Kételkedési hányados szerinti & 13. & 1. & 7. & 5. & 8. \\
rangsor & & & & & \\
MBTM(2) rangsor & 30. & 32. & 31. & 29. & 28. \\
MBTM(3) rangsor & 32. & 31. & 30. & 29. & 28. \\
MBTM(4) rangsor & 32. & 31. & 29. & 28. & 27. \\
\hline
\end{tabular}


1. ábra

A Sharpe-ráta és az MBTM rangsorolásának összehasonlítása különbözö kockázatelutasítási együtthatók mellett

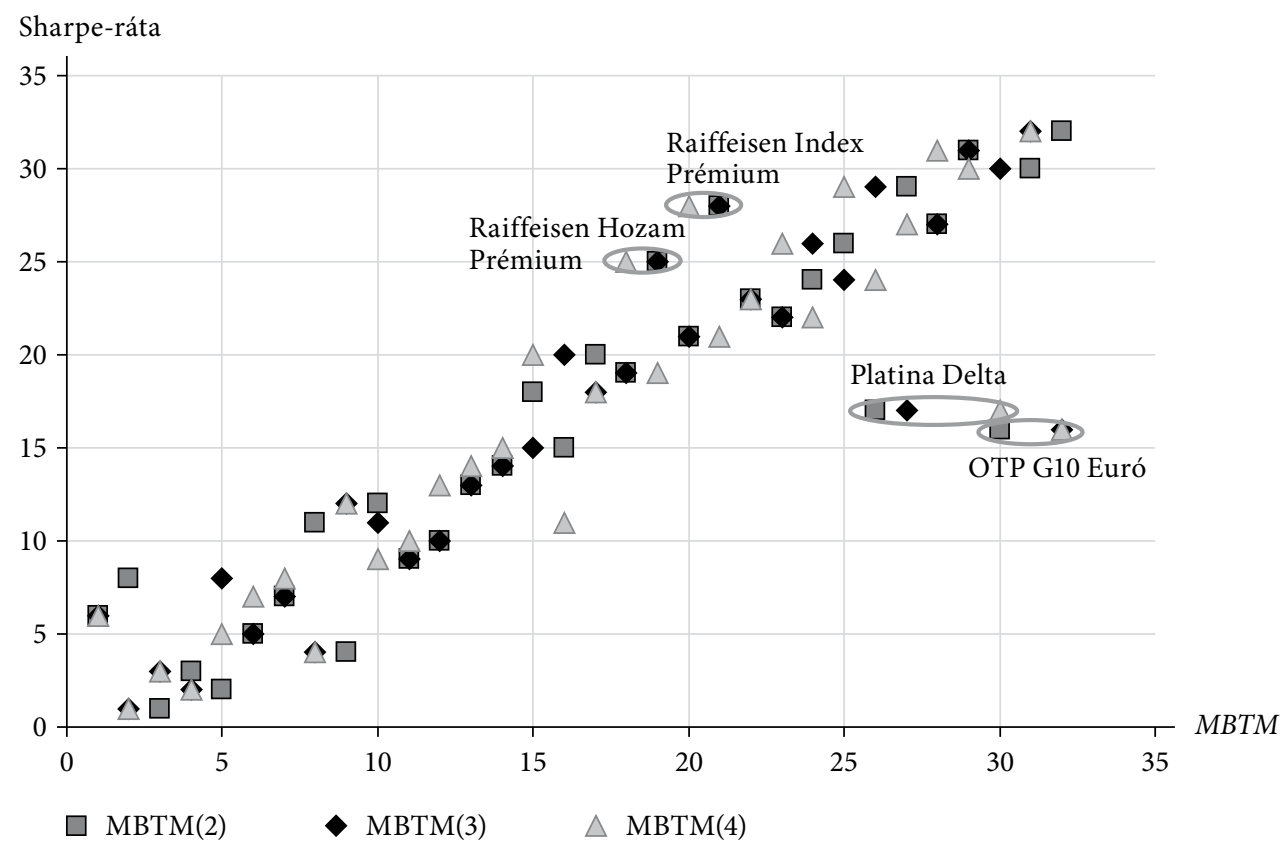

A hozammanipuláció, hozamsimitás nyomainak kimutatása különbözö módszerekkel

A következőkben a hozammanipuláció vagy hozamsimítás nyomait keressük különféle módszerekkel, a kételkedési hányados, illetve a torzítási ráta segítségével kiszürve azokat a befektetési alapokat, amelyek esetében a legmagasabb a valószínüsége hozammanipuláció meglétének.

A kételkedési hányados és a Sharpe-ráta segítségével a csoportátlagtól vett eltérésük alapján a hozammanipulációval legvalószínűbben gyanúsítható befektetési alapok csoportját azonosítjuk. Az öt legmagasabb kételkedési hányadossal rendelkező alapot láthatjuk 4. táblázatban.

A kételkedési hányados az 50-80 közötti sávban marad még ezen alapok esetében is, ami messze elmarad a gyanús jelzésnek számító, Brown és szerzőtársai [2010] által kritikusnak tekintett 150 körüli értékektől, így ezen módszer alapján nem találtuk nyomát hozammanipulációnak vagy hozamsimításnak. Ugyanakkor az is látható, hogy az MBTM nem változik jelentősen a különböző kockázatelutasítási hányadosokra néhány alap esetében, azaz az implikált kockázatelutasítás relatíve magas. Ugyan a legmagasabb öt kételkedési hányadosú alapból négy egyben a legmagasabb Sharpe-rátával rendelkező alap is, ám az öt alapból három az MBTM szerint is a legjobban teljesítő négy alap közé tartozik. A másik kettő is 
4. táblázat

A legmagasabb kételkedési hányadossal rendelkező alapok tulajdonságai

\begin{tabular}{lccccc}
\hline & Platina & Citadella & Aegon & Platina & Platina \\
& Pí & & ÓzonMaxx & Alfa & Béta \\
\hline Átlagos hozam & 9,40 & 9,61 & 3,78 & 9,21 & 6,46 \\
Az átlagos hozam szerinti rangsor & 5. & 4. & 21. & 6. & 11. \\
A hozam szórása & 4,67 & 4,47 & 0,92 & 4,19 & 2,78 \\
A hozam szórása szerinti rangsor & 14. & 12. & 1. & 10. & 6. \\
Sharpe-ráta & 1,24 & 1,34 & 0,17 & 1,33 & 1,02 \\
Sharpe-ráta szerinti rangsor & 3. & 1. & 15. & 2. & 4. \\
MBTM(2) & 0,05559 & 0,05795 & 0,00261 & 0,05433 & 0,02839 \\
MBTM(3) & 0,05450 & 0,05695 & 0,00256 & 0,05345 & 0,02800 \\
MBTM(4) & 0,05341 & 0,05595 & 0,00252 & 0,05258 & 0,02762 \\
Kételkedési hányados & 53,02 & 59,98 & 63,89 & 64,07 & 75,61 \\
Kételkedési hányados szerinti rangsor & 28. & 29. & 30. & 31. & 32. \\
MBTM(2) rangsor & 4. & 3. & 16. & 5. & 9. \\
MBTM(3) rangsor & 3. & 2. & 15. & 4. & 8. \\
MBTM(4) rangsor & 3. & 2. & 14. & 4. & 8. \\
\hline
\end{tabular}

a jól teljesítő top 15 része. Így mindezeket figyelembe véve nem állíthatjuk, hogy hozammanipuláció okozná ezen öt alap kiváló Sharpe-ráta-eredményét és rangsorát. Ugyanakkor a Sharpe-ráta-kételkedési hányados térben tekintve (2. ábra) ezen öt befektetési alap kiugrónak (outlier) tünik értékeivel a többi megfigyelt befektetési alaphoz képest, így esetükben legalábbis indokoltnak tünik további vizsgálatok elvégzése.

Abdulali [2006] vezette be a torzítási ráta (Bias Ratio) használatát a fedezeti alapok hozamainak elemzésére, amellyel kiszürhetők azok a fedezeti alapok, amelyek feltételezhetően hozamsimítást vagy más hozammanipulációt alkalmaznak, elsősorban a ritkán árazódó vagy nehezen értékelhető nettó eszközértékü portfólióelemeiken keresztül. A torzitási ráta (TR) konkrét mércéje az alapok eszközeinek értékelésében fellelhető torzításnak: a hozamok eloszlásának alakját a 0 hozam körüli 1-1 szórásnyi kritikus sávban méri [lásd a (4) képletet], jelezve azon fedezeti vagy befektetési alapokat, amelyek esetében felmerül a hozamsimítás vagy más manipuláció lehetősége. Az így kiszürt fedezeti alapokat azután részletesebb elemzéseknek érdemes alávetni.

$T R=\frac{\text { Megfigyelt gyakoriság }\left(r_{i}\right): r_{i} \in[0,+1,0 \sigma]}{1+\text { Megfigyelt gyakoriság }\left(r_{i}\right): r_{i} \in[-1,0 \sigma, 0)}$,

ahol $[0, \sigma]$ a 0 -t is magában foglaló zárt intervallum a hozamok +1 szórásáig bezárólag. A $[-\sigma, 0)$ a félig zárt intervallum a hozamok -1 szórásától 0 -ig, beleértve a -1 szórást is, de a 0 -t nem. A megfigyelt hozamokat $r_{i}$ jelöli. 
2. ábra

A legmagasabb kételkedési hányadossal rendelkező alapok elemzése.

Sharpe-ráta

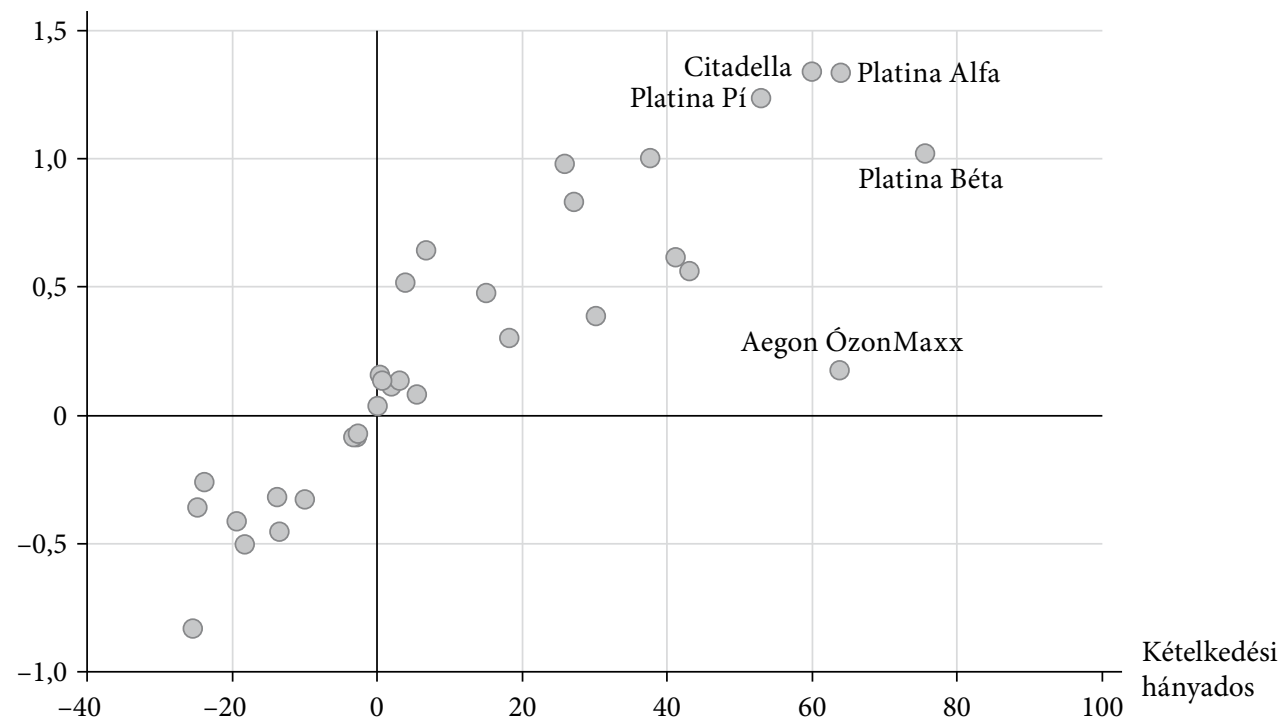

A torzitási ráta az első és a második kvartilis görbéje alatti terület arányát közelíti. Tulajdonságai a következők:

$1.0 \leq T R \leq n$, ahol $n$ a megfigyelt hozamok száma.

2. $\forall r_{i}$-re, ha $r_{i}<0$, akkor $T R=0$.

3. $\forall r_{i}$-re, ha $r_{i}>0, r_{i}>+1,0 \sigma$, akkor $T R=0$.

4. Ha $r_{i}$ normális eloszlást követ, 0 várható értékkel, akkor $T R \rightarrow 1$, ha $n \rightarrow \infty$.

A 0 átlagú és normális eloszlású fedezeti és befektetési alapoknak 1-nél kisebb a torzítási rátája, míg a nagy piaci indexeknek 1-nél nagyobb, a föbb részvényindexeknek pedig 1 és 1,5 közötti. A készpénzbe és diszkontkötvény-típusú eszközökbe fektető alapok és befektetési stratégiák relatíve konstans pozitív hozamokat generálnak, nagyon ritka veszteséges időszakokkal, aminek hatására eloszlásuk a 0 körül jobbra ferde, következésképpen magas a torzítási rátájuk is. Így a torzítási ráta használata kevésbé megbízható olyan befektetési alapok vagy fedezeti alapok esetében, amelyek magas készpénzjellegü befektetésekkel rendelkeznek. Az Abdulali [2006] által vizsgált részvényalapú fedezeti alapok torzítási rátái 0,3 és 3 között szóródtak, 1,29-os várható érték és 0,5 -es szórás mellett. Az eltérő befektetési stílust követő fedezetialap-csoportok esetében széles szórást mutatnak a torzítási ráta értékei, valamint az egyes csoportok átlagai és mediánjai.

A magyar abszolút hozamú befektetési alapok adatain végzett saját számításaink szerint a torzítási ráta értékei nagyrészt az 1,18 és 1,37 kvartilisek között összpontosulnak. Az átlag 1,34, míg a medián 1,28, a legkisebb érték 0,96, míg a legnagyobb 2,64. Abdulali [2006] szerint a torzítási rátát mint az esetleges hozamsimítás vagy hozammanipuláció jelzőrendszerét úgy érdemes használni, hogy az adott típusba 
tartozó befektetési vagy fedezeti alapok közül azokat vetjük részletesebb vizsgálat alá, amelyek a csoport torzitási rátájának a mediánja fölött helyezkednek el. Így Abdulali [2006] ajánlásait szigorúan követve a medián alapján 16, az átlag alapján 10 befektetési alapot érdemes további vizsgálatoknak alávetni a hozamsimítás vagy egyéb hozammanipuláció, kétes eszközértékelés nyomait keresve.

Ha csak azokra a befektetési alapokra összpontosítunk, amelyek értékei kiugrók a csoport többi tagjához képest, akkor az 1,53-nál magasabb torzitási rátájú befektetési alapokat érdemes vizsgálni, esetünkben az 5. táblázatban szereplő hat alapot.

\section{5. táblázat}

Kiugró torzitási rátájú befektetési alapok

\begin{tabular}{lc}
\hline Az alap neve & Torzítási ráta \\
\hline Aegon ÓzonMaxx & 2,64 \\
Erste DPM & 1,81 \\
Aegon MoneyMaxx & 1,70 \\
Raiffeisen Hozam Prémium & 1,56 \\
Aegon Smart Money & 1,54 \\
Citadella Származtatott & 1,54 \\
\hline
\end{tabular}

Az 1,53-os kritikus érték egybevágna Abdulali [2006] azon megfigyelésével is, hogy a föbb részvényindexek torzítási rátái 1 és 1,5 között szóródnak, és az abszolút hozamú befektetési alapok portfóliójában ezek mindenképp meghatározó részt tesznek ki. Fontos ugyanakkor megjegyeznünk, hogy bármelyik kritikus értéket is választjuk, önmagában a torzítási ráta alapján nem tudjuk teljes bizonyossággal kijelenteni, hogy a kritikus érték fölötti befektetési alapok biztosan hozammanipulációt vagy hozamsimítást alkalmaznak, csak azt, hogy az eloszlásukban 0 körül az 1-1 szórásnyi intervallumban tapasztalható aránytalanság erösen felveti ennek a gyanúját.

\section{A kételkedési hányados és a torzitási ráta összevetése, diszkontinuitáselemzés}

A következökben arra a kérdésre keressük a választ, hogy a torzitási ráta értékei és a kételkedési hányados értékei között milyen kapcsolat van, mennyiben fedi egymást a két módszer. Továbbá a diszkontinuitáselemzést felhasználva részletesebb értékelésnek vetjük alá a gyanúsnak elöminősített befektetési alapok hozameloszlását, hogy nagyobb bizonyossággal lehessen azonosítani a hozammanipuláció jelenlétét. Az eredmények alapján - a nemzetközi tapasztalatok ellenére - a kételkedési hányados kevésbé bizonyult megbízható elöjelző eszköznek, mint a torzítási ráta.

A kételkedési hányados és a torzitási ráta között a korrelációs együttható 0,35 , míg a rangkorreláció 0,22 , ami gyenge-közepes kapcsolatot jelez. Ha grafikonon ábrázoljuk a befektetési alapokat a torzitási ráta és a kételkedési hányados szerint, akkor megfigyelhetjük, hogy a kiugró értékek tekintetében milyen a kapcsolat (3. ábra). 
3. ábra

A torzítási ráta és a kételkedési hányados értékeinek összehasonlítása

Kételkedési hányados

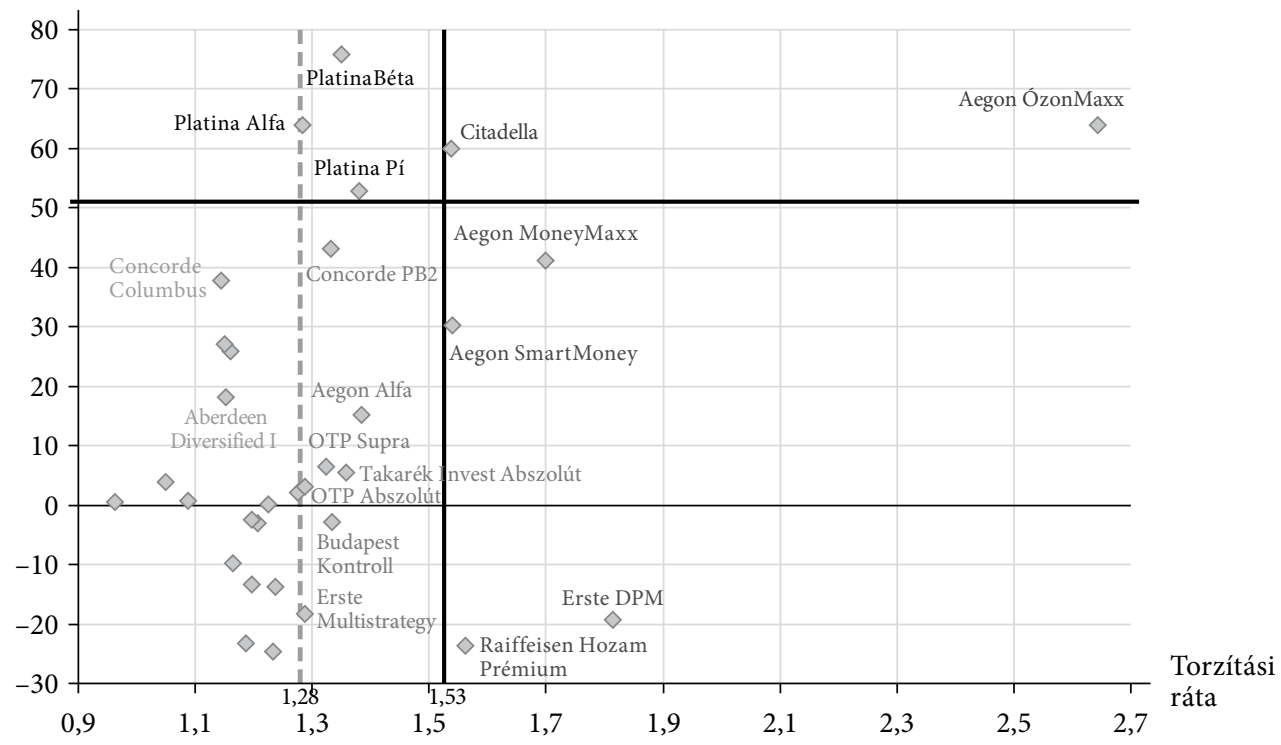

Bár a kételkedési hányados esetében az értékek elmaradtak a Brown és szerzötársai [2010] által kritikus értéknek meghatározott 150 körüli szintektől, így a mutató alapján egy befektetési alapról sem lehetett egyértelmủen megállapítani a hozammanipulációt, volt öt olyan befektetési alap, amelynek kiugró értékei voltak a Sharpe-rátát is figyelembe véve a megfigyelt többi befektetési alaphoz képest (2. ábra). Ezek rendre a Platina Pí, Citadella Származtatott, Platina Alfa, Aegon ÓzonMaxx és a Platina Béta. Ezek közül a Platina Pí, Platina Alfa, Platina Béta torzitási rátájának értéke 1,31,4 körüli (lásd a 3. ábra 50,0 kételkedési hányados feletti és 1,53 torzitási ráta alatti, bal felső részében), amivel még nem ütnek el látványosan a többi befektetési alap értékeitöl $(\mathrm{Q} 3=1,36)$. A 2. ábra kapcsán leírtak, valamint a 3. ábra alapján úgy értékeljük, hogy ezt a három befektetési alapot lényegesen eltérö értékekkel csak a kételkedési hányados különbözteti meg a többi befektetési alaptól, míg a torzítási ráta nem. Ugyanakkor Abdulali [2006] mediánszabálya (lásd a 3. ábrán az 1,28-os értéket szaggatott vonallal ábrázolva) alapján már gyanúsnak számítanak, és ezért indokolt részletesebb elemzésnek alávetni őket.

Az Aegon Smart Money, Raiffeisen Hozam Prémium, Aegon MoneyMaxx és Erste DPM a 3. ábrának az 50,0 kételkedési hányados alatti és az 1,53 torzitási ráta feletti jobb alsó részében helyezkednek el. Ugyanis ezeknek az 1,53-nál nagyobb torzítási rátái a csoporttól lényegesen kiugró értékei szerint a torzitási ráta potenciális hozamsimítottság vagy hozammanipuláltság gyanújával különbözteti meg a többi befektetési alaptól, viszont a kételkedési hányados szerint nincsenek kiugró értékeik.

Két befektetési alapot találunk, amelyet mind a kételkedési hányados, mind a torzitási ráta a megfigyelt többi befektetési alap csoportjától kiugró értékekkel 
különböztet meg, azaz bár egyik módszer sem jelöli meg őket egyértelműen hozamsimítónak vagy hozammanipulónak, mindkettő esetében itt tűnik a legvalószínübbnek a gyanú megalapozottsága. Ezeket a 3. ábra jobb felső részén találjuk: Citadella Származtatott és Aegon ÓzonMaxx. Ez utóbbi esetében a kilógó értékek igen szembeötlők: míg a torzítási ráta esetében a 2,64-os értékkel toronymagasan szerepel az 1 . helyen, az átlag közel duplájával és 0,83 -dal meghaladva még a 2. helyezett befektetési alapot is, addig a 64-es kételkedésihányados-értékkel tulajdonképpel holtversenyben szerepel a 2 . helyen (bár ténylegesen néhány századdal lemaradva a 2.-tól 3. a sorban).

Abdulali [2006] alapján további vizsgálatnak érdemes alávetni azokat a befektetési alapokat, amelyeknél a torzitási ráta értékei meghaladják a megfigyelt csoport mediánját, amely esetükben az 1,28-os kritikus érték, és ez 16 befektetési alapot érint. Részletesebb elemzésnek vetjük alá a befektetési alapok 0 körüli eloszlását, a diszkontinuitás jeleit keresve, amelyek szintén a potenciális hozamsimítást tanúsíthatják. Elméletben, ha hozamsimítás vagy az egyes illikvid eszközök kreatív értékelése áll a háttérben, akkor a közvetlenül 0 melletti pozitív és negatív hozamok gyakoriságát mutató oszlopokban/osztályokban aránytalanságot fedezhetünk fel a pozitív hozamok javára.

Ennek megfelelően diszkontinuitáselemzés során a hisztogramok elkészítéséhez Bollen-Pool [2009]-et követve Silverman [1986] képletét használjuk:

$h=0,9 \min \left[\sigma ; \frac{Q 3-Q 1}{1,34}\right] N^{-0,2}$,

ahol $h$ az osztályok szélessége, $\sigma$ a hozamok szórása, $N$ a megfigyelt hozamok száma, Q3 és Q1 pedig a megfelelő kvartilisek. Bollen-Pool [2009] alapján mind a $h$ meghatározásakor, mind a hisztogramok ábrázolásakor figyelmen kívül hagyjuk a kereken 0 hozamokat, mivel azok nem hozamsimítást jelentenek, hanem hiányzó adatokat vagy a kereskedés hiányát.

A 0 melletti pozitív és negatív hozamok gyakoriságában megfigyelhető aránytalanságok elemzéséhez a hisztogramokon megfigyelhető eloszlások lefutása mellett alkalmazott statisztikai tesztünk során az egyes 0 körüli osztályközök gyakoriságának a normális eloszláshoz való illeszkedése mérésére Bollen-Pool [2009], valamint Burgstahler-Dishev [1997] szerinti képletünk:

$Z=\frac{f-N p}{\sqrt{N p(1-p)}}$

ahol $f$ a megfigyelt gyakoriság az adott osztályközben, $N$ a megfigyelések száma, $p$ pedig az adott osztályköznek a várható értéke, amely az elemzésünk során a megfelelő momentumokkal rendelkező normális eloszlás eloszlásfüggvényéből számolt valószínüség.

Bollen-Pool [2009], Brown és szerzőtársai [2010] és Burgstahler-Dishev [1997] egyaránt azt találták, hogy a 0 melletti negatív hozamok szignifikáns negatív eltérést mutattak a várható értékükhöz képest, míg a pozitív hozamok pozitív irányban bizonyultak statisztikailag nagyobbnak a várható értéküknél, alátámasztva azt a hipotézist, 
hogy a 0 melletti pozitív hozamok gyakorisága feltehetően manipuláció eredményeképpen lett megnövelve a 0 melletti negatív hozamok ellenében. Ezzel szemben elemzésünk során több befektetési alap esetében azt találtuk, hogy a két osztályköz tekintetében tapasztalt eltérések iránya nem különbözik, ugyanakkor az eltérés mértéke többszörösen eltér a pozitív hozamok javára. Az eltérések nagyságrendjében megmutatkozó különbség tehát felhasználható számszerü jelzésként a diszkontinuitás meglététének megerősítésére a hisztogram lefutásának megfigyelése mellett.

Az elemzett 16 befektetési alapunk hisztogramjainak átvizsgálásakor azokra az esetekre figyeltünk, amelyekben a 0 melletti pozitív hozamok gyakorisága jelentősen nagyobb mértékben haladta meg a várható értékét, mint a 0 melletti negatív hozamok gyakorisága a saját várható értékét - hiszen ha ez nem áll fenn, akkor értelemszerủen a befektetési alap kezelője nem vádolható azzal, hogy igyekezett a 0 körüli pozitív hozamok arányát mesterségesen feljavítani a 0 melletti negatív hozamok rovására. Ezen esetekben a tesztstatisztikák arányában az 1,3 körüli érték bizonyult vízválasztónak, amelynél nagyobb értékek esetén a hisztogram lefutása is a diszkontinuitás meglétét erősítette meg, míg az ennél kisebb értékủ tesztstatisztika-hányadosok esetén a hisztogram lefutásában sincs egyértelmü jele a diszkontinuitásnak, azaz hozamsimításnak.

Azon esetek, ahol a 0 melletti negatív hozamok esetében a várható értéktől szignifikáns elmaradást tapasztalunk, míg a 0 melletti pozitív hozamok esetében szignifikáns meghaladást, egybevágnak Bollen-Pool [2009], valamint Brown és szerzőtársai [2010] megfigyeléseivel, és a szignifikáns eltérések már önmagukban azt valószínüsítik, hogy a 0 melletti pozitív hozamok gyakoriságát a 0 melletti negatív hozamok rovására mesterségesen növelték meg.

Két befektetési alap, amelyeket mind a kételkedési hányados, mind a torzítási ráta kirívóan gyanúsnak ítélt a hozamsimítás potenciális megléte szempontjából: a Citadella Származtatott, valamint az Aegon ÓzonMaxx befektetési alapok. A hisztogram megerősíti a 0 körüli diszkontinuitás meglétét a Citadella Származtatott Alap esetében, és így a feltételezhető hozamsimítást is, mivel mind a kisebb osztályszélesség, mind a kétszeres osztályszélesség esetén (4. ábra) is jelentős a 0 melletti pozitív hozamok fölénye: 150:250, valamint 238:387 arányban.

A normális eloszláshoz viszonyított tesztstatisztika értéke 8,7 a 0 melletti negatív és 20,1 a 0 melletti pozitív hozamok esetében, Silverman [1986] osztályközszélességével számolva, amelyek minden szokásos szignifikanciaszinten azt mutatják, hogy mindkét osztályköz esetében a tapasztalt gyakoriság nem követi a normális eloszlást, hanem jelentősen meghaladja azt (kritikus értékek 1,96 és 2,58). Ugyanakkor a 0 melletti pozitív hozamok sokkal inkább meghaladják a normális eloszlást, mint a 0 melletti negatív hozamok, a tesztstatisztika mintegy 2,3-szerese a negatív hozam esetében tapasztalt statisztikáénak. Kétszeres osztályközszélességgel számolva a tapasztalt tesztstatisztika értékei 7,5-19,6, azaz az eltérés mintegy 2,6-szeres.

Az Aegon ÓzonMaxx befektetési alap esetében is a potenciális hozamsimítás meglétére találunk nyomokat a hisztogram lefutását tekintve, mivel itt a 0 körüli közvetlen osztályok arányai rendre 139:205 és 209:390. A tesztstatisztikák arányai pedig $12,3: 21,2$ és 10,8:28,3, azaz 1,7 és 2,6. 


\section{4. ábra}

A Citadella Származtatott Alap hozamainak 0 körüli diszkontinuitáselemzése
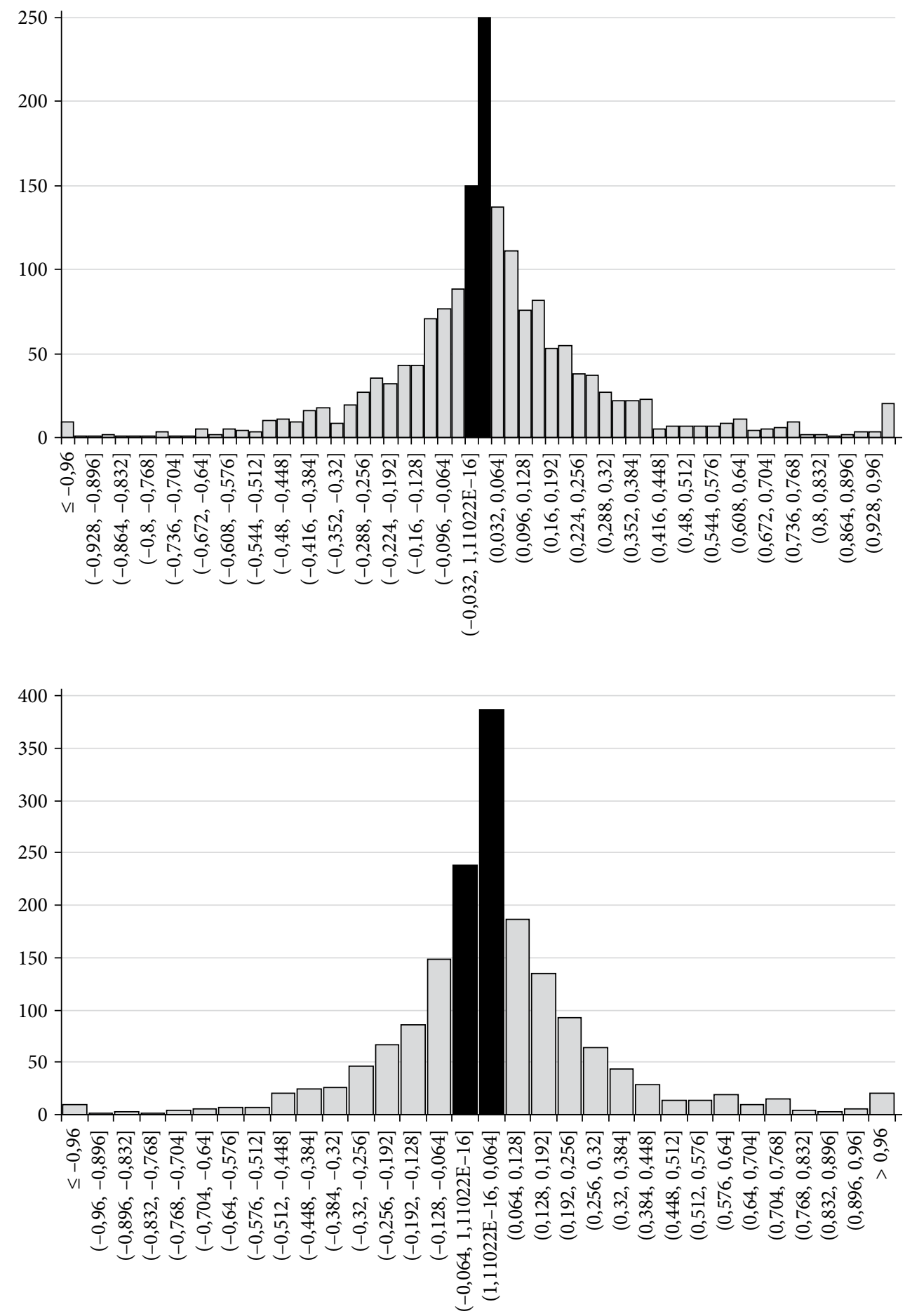
A torzitási ráta és a kételkedési hányados által a fentiekben kiszürt, a 3. ábra alapján hozamsimítással gyanúsítható további 14 befektetési alap esetében is elvégeztük a fenti diszkontinuitáselemzést a megfelelő osztályszélességü hisztogramok segítségével, amelyekből csak két olyan volt, amely nem mutatta semmilyen nyomát a diszkontinuitásnak, a többi esetben a diszkontinuitás erőssége szorosan együtt mozgott a torzítási ráta értékeivel.

Összefoglalva a diszkontinuitáselemzés eredményeit, a következő megfigyelésekre jutottunk.

- A kételkedési hányados alapján öt befektetési alap esetében látszik a legvalószínủbbnek a hozammanipuláció a csoportátlagtól való eltérésük alapján. Ebből az öt alapból három bizonyult hozamsimítottnak a hozamok diszkontinuitáselemzése alapján is.

- A torzítási ráta által a mediánt (1,28-ot) meghaladó és ezért elemzésre kijelölt befektetési alapból 16 van. Ezekből hat esetében nagy a valószínüsége a hozammanipulációnak a csoportátlagtól vett jelentős eltérés miatt, míg tíz esetében csak közepes a gyanú a mediánszabály alapján. Az előbbi hat esetében a diszkontinuitáselemzés megerősítette a hozamsimítás/hozammanipuláció lényeges/erős meglétét. Utóbbi tízből négy esetében a diszkontinuitáselemzés nem mutatta semmilyen jelét hozamsimításnak, öt esetében közepes-gyenge jeleit tapasztaltuk, míg egy esetében egyértelmü és erős jelzést tapasztaltunk. A torzitási ráta tehát 16-ból 12-szer megalapozottan vetette fel a hozammanipuláció valószínüségét.

A torzitási ráta alapján elemzésre kijelölt 16 befektetési alap magában foglalja a kételkedési hányados által a csoportátlagtól vett eltérés szerint kijelölt öt befektetési alapot. Két olyan alap van, amelyet a kételkedési hányados és a torzítási ráta is nagy valószínüséggel mutat hozammanipuláltnak, és ezt a gyanút a hozamok diszkontinuitáselemzése is megerősíti. Egy olyan befektetési alap van, amelyet a diszkontinuitáselemzés is egyértelmüen hozamsimítottnak értékel, és a kételkedési hányados a csoportátlagtól való eltérés miatt jelöl meg, míg a torzítási ráta a csoportátlagtól való eltérés alapján nem, csak a mediánszabály szerinti gyengébb megkülönböztetéssel. Négy olyan befektetési alapot találtunk, amelyeket a csoportátlagtól vett eltérés alapján a torzítási ráta erősen gyanúsnak jelez, és a diszkontinuitáselemzés is erősen-közepesen erősen hozamsimítottnak mutat, míg a kételkedési hányados nem különbözteti meg őket. A torzitási ráta alapján gyengén gyanúsnak ítélt tíz befektetési alapból hat bizonyult megalapozott gyanúnak a diszkontinuitáselemzés szerint, ám a kételkedési hányados e tíz befektetési alap esetében nem jelzett gyanút.

Összegezve tehát az elemzett 32 befektetési alapból álló mintán a kételkedési hányados öt alap esetén jelezte a hozamsimítás gyanúját, és ebből háromszor bizonyult a jelzés megbízhatónak. A torzítási ráta pedig a csoportátlaghoz viszonyított erös jelzés alapján hatból hatszor bizonyult megbízhatónak, míg a gyengébb, mediánalapú jelzés esetében tízből hatszor, azaz összességében, mindkét jelzését figyelembe véve, 16-ból tízszer. Így a torzítási ráta az elemzett minta alapján a hozamsimítás megbízhatóbb jelzőjének tủnik, mint a kételkedési hányados. Ugyanakkor 
figyelembe kell vennünk, hogy a kételkedési hányadost pusztán a csoporthoz viszonyítva kirívóan eltérő értékkel rendelkező befektetési alapok azonosításán keresztül lehetett használni a mintán, mivel a 150-es kritikus értéket egyik befektetési alap sem érte el. Fontos tényező még, hogy az elemzés viszonylag kis mintán készült, így nem tekinthetjük általánosan bizonyítottnak, hogy ez az eltérés nagyobb mintákon is azonos arányban mutatkozna meg a két mutató között. Továbbá azt is érdemes figyelembe vennünk, hogy a kételkedési hányados az implikált kockázatelutasítást méri, és kapcsolatot teremt a hozamok és a vállalt kockázat között a manipulációbiztos teljesítménymutatókon (MBTM) keresztül, míg a torzítási ráta csak a hozamok eloszlását elemzi.

\section{Összegzés}

A klasszikus teljesítménymérő mutatószámok alkalmazása problémás az abszolút hozamú befektetési alapok esetében, mivel azok nem követnek referenciaértékeket, így a piaci hozamok/referenciahozamok, valamint az alapkezelö egyéni döntéseiből fakadó hozamok összekeverednek. E befektetési alapok abnormális hozameloszlása a derivatívák alkalmazásának köszönhetően, valamint a lehetséges hozamsimítás és teljesítménymanipuláció olyan akadályok, amelyeket a klasszikus mutatószámok segítségével nehéz kezelni.

A manipulációbiztos teljesítménymutatók (MBTM) használhatók e problémák áthidalására, és segíthetnek a befektetőknek azonosítani azokat az alapkezelőket, amelyek a befektetési tevékenységük során képesek valódi hozzáadott érték előállítására. Az MBTM segítségével lehetséges az implikált kockázatelutasitási hányadosok (kételkedési hányadosok) számítása, amivel a teljesítménymanipulálás/hozamsimítás nyomai feltárhatók. E mutatószámokat elsőként alkalmaztuk magyar befektetési alapok teljesítményértékelésére, valamint a hozammanipuláció nyomainak kimutatására.

A magyar abszolút hozamú alapok esetében az MBTM és a Sharpe-ráta közötti rangkorrelációk 0,87-0,9 tartományban mozogtak, ami ugyan magasabb a nemzetközi példák 0,7 körüli tartományánál, de a klasszikus mutatószámokhoz viszonyítva jelez annyi eltérést, amelyeket okozhat valamilyen szintü hozammanipuláció vagy hozamsimítás. Saját számításainknak a szakirodalomhoz hozzájáruló új eredménye, hogy a kételkedési hányadosnak a szakirodalomban megfigyelt, az alternatív hozammanipulációt kimutató módszerekkel való szoros átfedésével (Brown és szerzőtársai [2010] alapján 80 százalékos egyezés) szemben az elemzett mintánkon felemás eredményeink születtek: az alternatív módszerek a 32 befektetési alapból tágabban értelmezve 16, szigorúbb megközelítés szerint pedig hat esetben jeleztek jelentős anomáliát, azaz hozammanipulációt nagy valószínüséggel, míg a kételkedési hányados csak öt befektetési alapot jelölt meg gyanúsnak, és abból csak hármat erősítettek meg az alternatív módszerek is.

Összességében tehát az eredményeink szerint a torzitási ráta jobb előszürő eszköznek bizonyult a hozammanipuláció részletesebb elemzéséhez (például diszkontinuitáselemzéssel), mint a kételkedési hányados. Ugyanakkor figyelembe kell 
vennünk, hogy a kételkedési hányadost pusztán a kiugró értékek (outlier) azonosításán keresztül lehetett használni az elemzett mintán, mivel a 150-es kritikus értéket egyik befektetési alap sem érte el, és az elemzés viszonylag kis mintán készült, így nem tekinthetjük általánosan bizonyítottnak, hogy ez az eltérés nagyobb mintákon is ugyanígy mutatkozna meg.

\section{Hivatkozások}

Abdulali, A. [2006]: The Bias Ratio: Measuring the Shape of Fraud. Protégé Partners, Quarterly Letter. https://www.protegepartners.com/www5/files/whitepapers/BiasRatio MeasuringShapeOfFraud.pdf.

Acerbi, C.-TAsche, D. [2002]: On the Coherence of Expected Shortfall. Journal of Banking and Finance, Vol. 26. No. 7. 1487-1503. o. https://doi.org/10.1016/s0378-4266(02)00283-2.

Arrow, K. J. [1971]: Essays in theory of risk-bearing. North-Holland, Amszterdam. https:// doi.org/10.2307/2978877.

Bollen, N.-Pool, V. [2009]: Do Hedge Fund Managers Misreport Returns? Evidence from the Pooled Distribution. Journal of Finance, Vol. 64. No. 5. 2257-2288. o. https://doi. org/10.1111/j.1540-6261.2009.01500.x.

Brown, S. J.-Kang, M.-In, F. H.-Lee, G. [2010]: Resisting the Manipulation of Performance Metrics: An Empirical Analysis of the Manipulation-Proof Performance Measure. Finance and Corporate Governance Conference Paper, https://doi.org/10.2139/ssrn.1536323.

Burgstahler, D.-Dishev, I. [1997]: Earnings management to avoid earnings decreases and losses. Journal of Accounting and Economics, Vol. 24. No. 1. 99-126. o. https://doi. org/10.1016/s0165-4101(97)00017-7.

Erdős Péter-Ormos Mihály-Zibricky Dávid [2011]: Non-parametric and semiparametric asset pricing. Economic Modelling, Vol. 28. No. 3. 1150-1162. o. https://doi. org/10.1016/j.econmod.2010.12.008.

Friend, I.-Blume, M. E. [1975]: The demand for risky assets. American Economic Review, Vol. 65. No. 5. 900-922. o.

Gandelman, N.-Hernandez-Murillo, R. [2015]: Risk Aversion at the Country Level. Review, Vol. 97. No. 1. 53-66. o. https://doi.org/10.20955/r.2015.53-66.

Hasanhodzic, J.-Lo, A. W. [2007]: Can Hedge Fund Returns Be Replicated? The Linear Case. Journal of Investment Management, Vol. 5. No. 2. 5-45. o. https://doi.org/10.2139/ ssrn.924565.

Ingersoll, J.-Spiegel, M.-Goetzmann, W.-Welch, I. [2007]: Portfolio Performance Manipulation and Manipulation-proof Performance Measures. The Review of Financial Studies, Vol. 20. No. 5. 1503-1546. o. https://doi.org/10.1093/rfs/hhm025.

JENSEN, M. [1969]: Risk, the pricing of capital assets, and the evaluation of investment portfolios. Journal of Business, Vol. 42. No. 2. 167-247. o. https://doi.org/10.1086/295182.

Jorion, P. [1996]: Risk2: Measuring the risk in Value at Risk. Financial Analysts Journal, Vol. 52. No. 6. 47-56. o. https://doi.org/10.2469/faj.v52.n6.2039.

Kydland, F. E.-Prescott, E. C. [1982]: Time to build and aggregate fluctuations. Econometrica, Vol. 50. No. 6. 1345-1370. o. https://doi.org/10.2307/1913386.

Layard, R.-Mayraz, G.-Nickell, S. [2008]: The Marginal Utility of Income. Journal of Public Economics, Vol. 92. No. 8-9. 1846-1857. o. https://doi.org/10.1016/j.jpubeco. 2008.01.007. 
Mas-Colell, A.-Whinston, M. D.-Green, J. R. [1995]: Microeconomic Theory. Oxford University Press, Oxford.

Modigliani, F.-Modigliani, L. [1997]: Risk-Adjusted Performance. Journal of Portfolio Management, Vol. 23. No. 2. 45-54. o. https://doi.org/10.3905/jpm.23.2.45.

Pojarliev, M.-Levich, R. M. [2013]: Evaluating Absolute Return Managers. Financial Markets and Portfolio Management, Vol. 28. No. 1. 95-103. o. https://doi.org/10.1007/s11408013-0224-7.

Rockafellar, R.-Uryasev, S. [2001]: Conditional value-at-risk for general loss distributions. Tech. rep., ISE Dept. working paper, No. 5. University of Florida. https://doi.org/10.2139/ ssrn.267256.

Sharpe, W. A. [1966]: Mutual Fund Performance. Journal of Business, Vol. 39. No. 1. 119-138. o. https://doi.org/10.1086/294846.

Silverman, B. W. [1986]: Density Estimation for Statistics and Data Analysis. Chapman and Hall, London-New York.

Sortino, F. A. [2001]: From Alpha to Omega. Megjelent: Sortino, F. A.-Satchell, S. E. (szerk.): Managing Downside Risk in Financial Markets. Reed Educational and Professional Publishing Ltd., 3-25. o. https://doi.org/10.1016/b978-075064863-9.50002-5.

Sortino, F. A.-Van Der Meer, R. [1991]: Downside Risk. Journal of Portfolio Management, Vol. 17. No. 4. 27-31. o. https://doi.org/10.3905/jpm.1991.409343.

Szpiro, G. G.-Outreville, J.-F. [1988]: Relative Risk Aversion Around the World. Further Results. The Journal of Banking and Finance, Vol. 6. No. 1. 127-128. o. https://doi. org/10.1016/0378-4266(88)90063-5.

Treynor, J. [1965]: How to Rate Management of Investment Funds. Harward Business Review, Vol. 43. 63-75. o. https://doi.org/10.1002/9781119196679.ch10.

Treynor, J.-Black, F. [1973]: How to Use Security Analysis to Improve Portfolio Selection. The Journal of Business, Vol. 46. No. 1. 66-86. o. https://doi.org/10.1086/295508.

WALter György [2002]: VaR-limitrendszer melletti hozammaximalizálás: a kaszinóhatás. Közgazdasági Szemle, 49. évf. 3. sz. 212-234. o.

ZAWADOWSKi ÁDÁm [2017]: Kezelési költségük határozza-e meg a Magyarországon forgalmazott részvénypiaci befektetési alapok teljesítményét? Közgazdasági Szemle, 64. évf. 11. sz. 1186-1201. o. https://doi.org/10.18414/ksz.2017.11.1186. 